\title{
Life cycle, seasonal and interannual polymorphism in a monoecious aphid Cinara mordvilkoi (Hemiptera: Aphidoidea: Lachnidae)
}

\author{
ROMA DURAK \\ University of Rzeszow, Department of Invertebrate Zoology, Zelwerowicza 4, 35-601 Rzeszów, Poland; \\ e-mail: rdurak@univ.rzeszow.pl
}

Key words. Hemiptera, Aphidoidea, Lachnidae, Cinara sp., aphid, polymorphism, male, life cycle

\begin{abstract}
This paper presents the first description of the life cycle of Cinara mordvilkoi and alary dimorphism of its males. There are 3 phases in its life cycle and during the course of a year 10 generations of parthenogenetic females are produced. The durations of development of subsequent generations over three years were recorded. C. mordvilkoi was observed to change its feeding position on its host from leaves to roots throughout the year. In the third year of this study both winged and wingless males were recorded. The fundatrix, oviparous female and the apterous and winged males are described.
\end{abstract}

\section{INTRODUCTION}

The characteristic features of aphids, such as telescopic development, short generation time of each generation, parthenogenesis, the diversity of life cycles, high fecundity and a small body size enable aphids to spread easily and adapt quickly to changing environmental conditions. One of the adaptive mechanisms is polymorphism, i.e. the ability to form phenotypically different morphs (Kawada, 1987; Miyazaki, 1987; Caillaud et al., 2002). This phenomenon is recorded most frequently in females and is called polyphenism; it includes fundatrices, winged viviparous females, wingless viviparous females and oviparous females (Dixon 1977, 1998; Minks \& Harrewijn, 1987). Their morphological and anatomical traits are adapted to the functions they perform and are induced by environmental factors. Males can also be polymorphic, however, unlike females, in their case it is genetically induced (Smith \& MacKay, 1989; Caillaud et al., 2002). Winged males occur in most species of aphids; the males of all host-alternating species are winged (Blackman \& Eastop, 1994). Only the males of Eriosomatidae, Hormaphididae, Anoeciidae and some Lachnidae are wingless. There is no host alternation among Lachnidae.

Polymorphism, in non-host alternating species of aphids is especially marked as almost genetically identical males and females infest the same host plant (Helden \& Dixon, 1997; Dedryver et al., 1998). This phenomenon is very important in aphids because in most of their annual life cycle they breed asexually (parthenogenesis) and in only one generation do they breed sexually (Dixon, 1977; Huang \& Caillaud, 2012).

The aphids belonging to Cinara sp. infest coniferous plants belonging to Pinaceae and Cupressaceae (Blackman \& Eastop, 1994). Cinara (Cupressobium) mordvilkoi (Pašek, 1954) is a monophagous species living only on Juniperus communis L. It is known only from European countries such as Sweden, Slovakia, Italy, Bulgaria,
Ukraine, Belarus, Latvia, Lithuania, Estonia, Poland and the Czech Republic (Blackman \& Eastop, 1994; Binazzi, 1996). It is also reported from $J$. turkestanica (= pseudosabina) in Kazakhstan. The species infests young shoots and branches. In Europe it is holocyclic. The sexual individuals occur in October in Poland (Herczek et al., 1977). The males of this species are wingless according to Blackman \& Eastop (1994).

This species is very difficult to observe in its natural habitat and in Poland it is reported only from 2 localities (Szelegiewicz, 1962; Herczek et al., 1977). It is also hard to distinguish from other species. Klimaszewski et al. (1977) distinguish it from Cinara juniperi (De Geer) on the basis of the composition of its haemolymph. It can also be identified by analyzing its mitochondrial DNA (Durak, 2011). The little information on this species is due to its cryptic life style. Its biology is still unknown and only the wingless parthenogenetic female (Pašek, 1954) and winged female (Binazzi, 1996) are described.

The aim of the paper was to investigate the life cycle and seasonal and interannual polymorphism in C. mordvilkoi.

\section{MATERIAL AND METHODS}

\section{Experimental procedures}

This study was conducted from 2009 to 2011 in the field in Poland. The bionomy of this species was studied from the beginning of March till the end of October. The plants with aphids were kept outdoors so that the aphids experienced the typical temperature conditions for this geographical region. C. mordvilkoi were reared on Juniperus communis. To prevent aphids from escaping I used clip cages that I put on the twigs with aphids (one clip cage for one apterous virginopara). Aphids were derived from different fundatrices, therefore each line that was followed represents a single clone and was potentially genetically distinct. The first larvae they bore marked the beginning of a new generation. Next they were transferred to another clip cage; there their fecundity and the length of particular developmental periods were recorded. In each generation the development of ten females was followed 

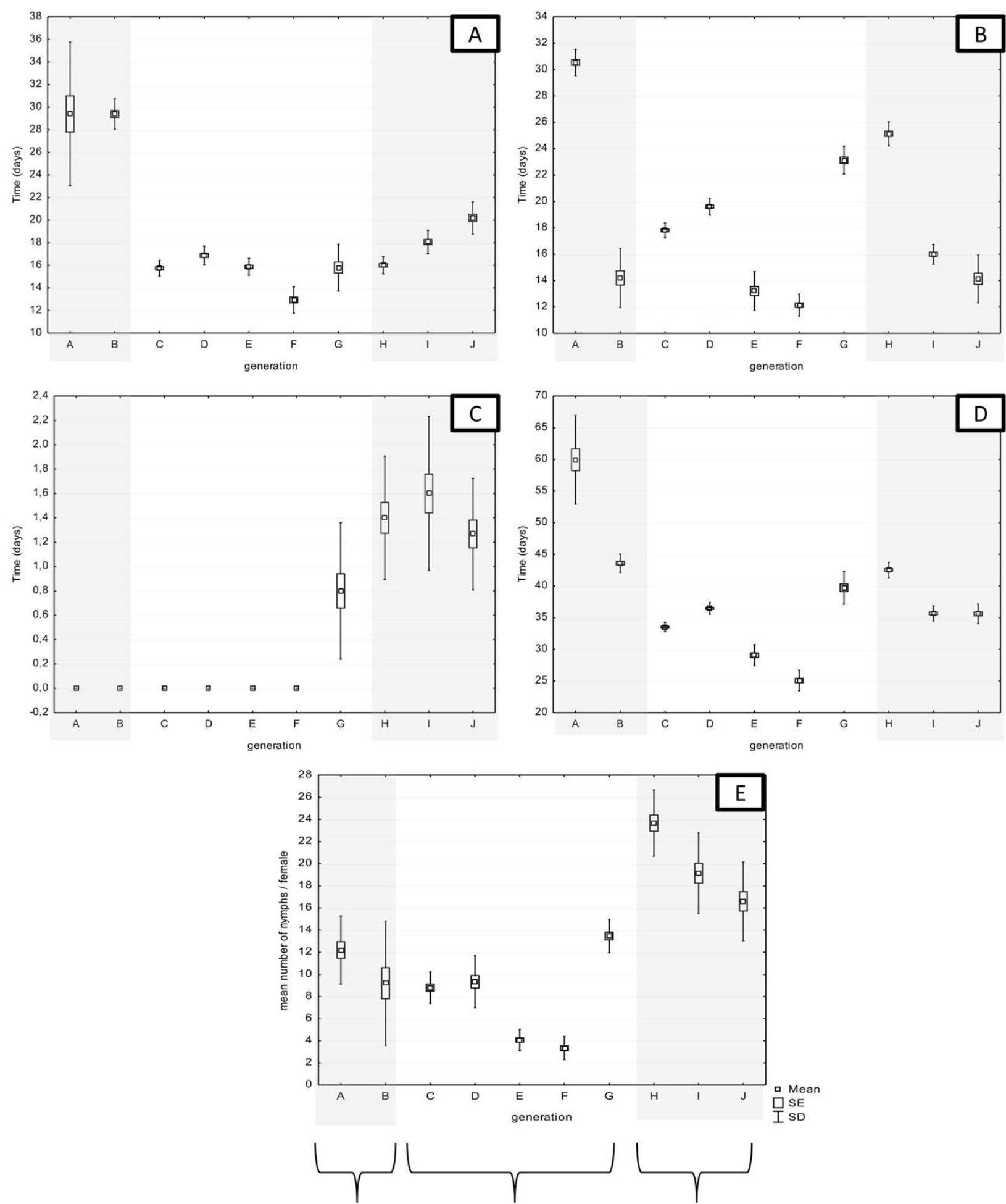

I

II

III

spring generations;

summer generations; autumn generations;

A: fundatrices, B: winged $\quad C-G$ : wingless

parthenogenetic females; parthenogenetic

branches and shoots

females;

$\mathrm{H}-\mathrm{J}$ : wingless parthenogenetic

females;

young shoots

roots and branches

close to the ground

Fig. 1. Mean durations in generations A-J of the prereproductive (A); reproductive (B) and postreproductive periods (C); their longevities (D) and fecundities (E). I-III - phases in life cycle. The mean \pm SE for three years are presented. 


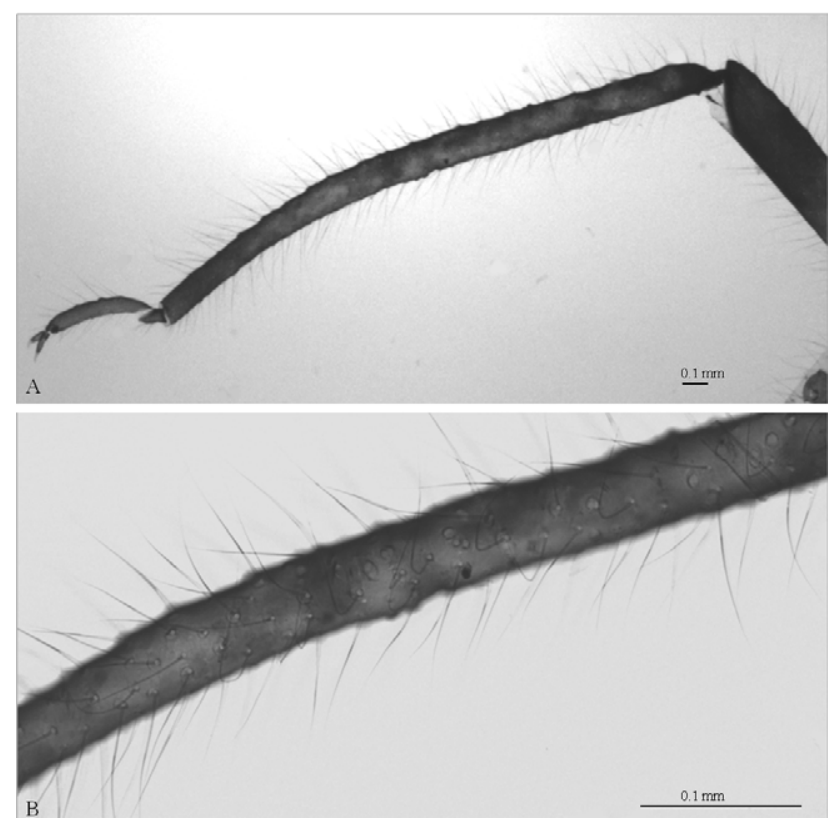

Fig. 2. Cinara mordvilkoi - oviparous female; A - hind tibia, $\mathrm{B}-$ sensoria on hind tibia.

by monitoring them five times a week. Generations were designated "A" to "J".

\section{Statistical analysis}

The lengths of the pre-reproductive, reproductive and postreproductive periods, life span and fecundity of the different generations were analyzed using ANOVA, StatSoft (2010), STATISTICA, version 9.0, www.statsoft.com. Data were tested for normality and analyzed using Kruskal-Wallis test.

\section{Morphological analysis}

In order to measure the body parts of particular morphs microscopic preparations were made. The specimens were examined using an Olympus BX 51 microscope.

The lengths of the following aphid body parts were measured: body, femur, III, IV, V and VI segments of antennae and rostrum. The numbers of secondary rhinaria on segments of the antennae of males were counted. Microscope slides are deposited in the Department of Invertebrate Zoology of the University of Rzeszow (Poland).

\section{RESULTS}

In consecutive years 10 parthenogenetic generations of C. mordvilkoi (A-J) were recorded (Fig. 1). Winged females occurred only in the second generation, while other generations consisted of only wingless females. Sexual morphs occurred in the $11^{\text {th }}$ generation (amphigonic females and males). In two years only wingless males were

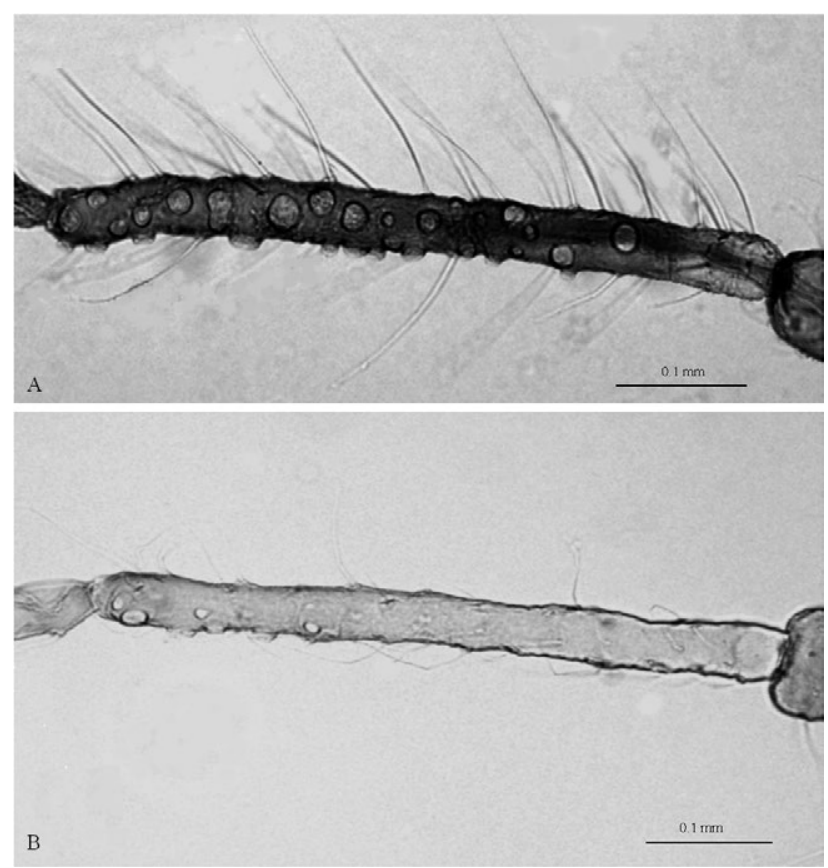

Fig. 3. Cinara mordvilkoi - antennal segment III; A - alate male, $\mathrm{B}$ - apterous male.

recorded but in the third one wingless and several winged ones occurred at the same time. The lengths of particular developmental stages of the females in the different generations were analyzed.

The pre-reproductive stage lasted on average from 12.2 to 34.8 days. The longest development period was reported for the individuals of A generation, and the shortest for those of $\mathrm{F}$ generation (Fig. 1A). The reproductive period lasted on average from 11.4 to 31.2 days (Fig. 1B). The longest reproductive period was recorded for A generation and the shortest for $\mathrm{F}$ generation. The post-reproductive period lasted on average 0 to 1.8 days (Fig. 1C). The mean total life span of aphids ranged from 23.6 to 66 days (Fig. 1D). The individuals of $\mathrm{A}$ generation lived the longest, those of $\mathrm{F}$ generation the shortest. The average fecundity of females ranged from 2.2 in B generation to 25 offspring in $\mathrm{H}$ (Fig. 1E). The fecundity of consecutive generations differed significantly.

Detailed data on significant differences in the lengths of all the developmental stages of the different aphid generations studied are presented in Table 1. There were no significant differences in the lengths of the developmental periods in consecutive generations between years.

TABLE 1. Differences in average lengths of the different stages in development (prereproductive, reproductive, postreproductive and longevity) and fecundity of different generations of the aphid. A-J - subsequent generations. Tested using Kruskal-Wallis test (H value of test, significance level at 0.05 , NS - not significant).

\begin{tabular}{cccc}
\hline Period & Difference in season & H & $\mathrm{p}$ \\
\hline Prereproduction & A-C; A-F; A-G; A-E; A-H; A-F; B-F; B-G; J-F; J-G & $\mathrm{H}=137.38$ & $\mathrm{p} \leq 0.05$ \\
Reproduction & A-B; A-E; A-F; A-J; E-G; E-H; F-H; F-G & $\mathrm{H}=144.13$ & $\mathrm{p} \leq 0.05$ \\
Postreproduction & - & $\mathrm{H}=133.90$ & $\mathrm{NS}$ \\
Life span & A-C; A-E; A-F; B-F; F-H & $\mathrm{H}=142.46$ & $\mathrm{p} \leq 0.05$ \\
Fecundity & B-H; B-I; B-J; E-H; E-I; F-H, F-I; & $\mathrm{H}=135.46$ & $\mathrm{p} \leq 0.05$ \\
\hline
\end{tabular}


TABLE 2. Morphological features of C. mordvilkoi $(\mathrm{n}=20)$. Mean (minimum - maximum).

\begin{tabular}{ccccc}
\hline \multirow{2}{*}{ Characters } & \multicolumn{4}{c}{ Length measurments (mm) morphs of C. mordvilkoi } \\
\cline { 2 - 5 } & fundatrix & oviparous & alate male & apterous male \\
\hline body length & $3.1(2.9-3.5)$ & $3.2(2.8-3.9)$ & $2.32(2.25-2.42)$ & $2.08(1.72-2.25)$ \\
ant. segm. III & $0.43(0.40-0.45)$ & $0.43(0.41-0.49)$ & $0.49(0.48-0.51)$ & $0.40(0.32-0.42)$ \\
ant. segm. IV & $0.16(0.12-0.19)$ & $0.17(0.15-0.19)$ & $0.22(0.21-0.25)$ & $0.17(0.14-0.20)$ \\
ant. segm. V & $0.23(0.21-0.24)$ & $0.24(0.22-0.25)$ & $0.26(0.20-0.28)$ & $0.22(0.18-0.26)$ \\
ant. segm. VI & $0.26(0.25-0.26)$ & $0.26(0.25-0.27)$ & $0.27(0.23-0.31)$ & $0.24(0.21-0.27)$ \\
antennae length & $1.08(1.02-1.13)$ & $1.11(1.04-1.21)$ & $1.24(1.17-1.27)$ & $0.99(0.85-1.13)$ \\
apical segm. of rostrum & $0.28(0.26-0.28)$ & $0.27(0.26-0.29)$ & $0.22(0.22-0.23)$ & $0.22(0.21-0.22)$ \\
tibia length & & $1.76(1.63-1.89)$ & & $(9-11)$ \\
no. of rhinaria: ant. segm. III & & & $(32-34)$ & $(4-7)$ \\
no. of rhinaria: ant. segm. IV & & & $(8-9)$ & $(3-5)$ \\
no. of rhinaria: ant. segm. V & & & $(3-4)$ & \\
\hline
\end{tabular}

The species lifecycle involves them actively changing their feeding site on the plant, which is associated with seasonal changes in temperature. A high air temperature causes them to migrate to the roots or branches close to the ground. Only the early spring (A-B) and autumn generations $(\mathrm{H}-\mathrm{J})$ develop on plant parts above the ground, i.e. young shoots and needles. The aphids spend the remaining part of the season on the roots and branches covered with soil, close to collar roots (Fig. 1.). They prefer shaded and humid habitats and have a cryptic way of life. Hence it is very difficult to find them in summer. It is mainly the autumn generations that are observed because this aphid infests young shoots after vacating the lower parts of plants. They can form combined colonies with $C$. juniperi.

A very interesting phenomenon, first reported here for this species, is the production of both wingless and winged males depending on the year. Both kinds of males were sexually active and copulated with females, which then laid overwintering eggs, which hatched on 29.03, 02.04 and 09.04 in consecutive years. The ratio of sexes in this species was 1 male : 6 females.

\section{Morphological analysis}

Fundatrix. Body length about $3.1 \mathrm{~mm}$, dark brown in colour, similar to viviparous females. The lengths of particular body parts are listed in Table 2. Infests young shoots.

Oviparous female. Similar to apterous viviparous females but slightly larger. Body length about $3.2 \mathrm{~mm}$. Antennal length about $1.1 \mathrm{~mm}$. Hind tibia slightly swollen with small sensoria along most of their length (Fig. 2, Table 2).

Alate male. Body blackish brown, length about 2.32 $\mathrm{mm}$. Antennae about $1.24 \mathrm{~mm}$ long. Ant. segm. III with 32-34 secondary rhinaria, IV with 8-9, V with 3-4 (Fig. 3 A, Table 2).

Apterous male. Similar to alate male, body length about $2.08 \mathrm{~mm}$. Antennae about $0.99 \mathrm{~mm}$ long. Ant. segm. III with 9-11 secondary rhinaria, IV with $4-7, \mathrm{~V}$ with $3-5$ (Fig. 3B, Table 2).

\section{DISCUSSION}

During the course of a season C. mordvilkoi completes 10 generations on $J$. communis. Similar numbers of gen- erations are reported for other Cinara sp., e.g. Cinara cupressi-9 and Cinara tujafilina 9-10 generations (Mustafa, 1987; Durak et al., 2007; Durak, 2014). The life cycle of C. mordvilkoi can be divided into 3 phases: I - early spring generations, which develop on the above ground parts of its host plant, consisting of a fundatrix and winged parthenogenetic females; II - summer generations, which infest roots or branches close to the ground, partly covered with soil, consisting of wingless parthenogenetic females; III autumn generations, which infest young shoots consisting of both parthenogenetic and sexual generations (Fig. 1). This vertical movement of the aphid on its host plant is associated with seasonal changes in temperature and humidity. Such behaviour, i.e. the migrating of monoecious species of aphids to tree trunks and roots is reported also for other species, e.g. Cinara piceae, is thought to be adaptive and a means of escaping adverse environmental conditions (Dixon, 1998).

The long pre-reproductive periods recorded for fundatrices and winged females are significantly longer than that of other generations. The lengths of the pre-reproductive periods of summer generations were similar but slightly shorter than those of the autumn generations. The duration of development depends mainly on temperature and is shortest at the optimal temperature for aphid development, i.e. about $20^{\circ} \mathrm{C}$. It is longer at temperatures lower or higher than $20^{\circ} \mathrm{C}$ (Durak \& Borowiak-Sobkowiak, 2013). Very long reproductive periods were recorded for both the fundatrices and autumn generations. It is a characteristic trait also of the fundatrices of other species e.g. C. cupressi (Durak et al., 2007), Amphorophora idaei, Aphis idaei (Borowiak-Sobkowiak, 2005, 2006) and Appendiseta robiniae (Borowiak-Sobkowiak \& Durak, 2012). Most spring and summer generations do not have post-reproductive periods, whereas the autumn generations typically do, as is also recorded for C. cupressi (Durak et al., 2007). The fundatrices and autumn generations had the longest life spans. Summer generations, feeding underground, had comparatively short average life spans and short pre-reproductive periods. Fundatrices were highly fecund, however, the highest fecundity was recorded for the autumn generations, in which females gave birth to as many as 25 larvae. The 
high fecundity of autumn generations is associated with preparing to switch to sexual reproduction.

The fecundity of C. mordvilkoi is, however, rather low compared to that of other Cinara sp. For C. cupressi it is about 45 larvae for fundatrices and about 30 for females in the 8th generation (Durak et al., 2007). The mean fecundity of generation 5 of $C$. tujafilina is also about 40 larvae (Durak, 2014). It is likely that the low fecundity recorded for particular generations of C. mordvilkoi accounts for the difficulty of finding this species in its natural habitat.

The occurrence of wingless and winged males in this species is interesting. Most of the species of Cinara sp. have winged males. It must be borne in mind that wingless males of monoecious species of aphids evolved from winged ones that did not have to migrate (Minks \& Harrewijn, 1987).

The occurrence of a wingless male is thus a rare event and is reported only for about 20 species of the 200 belonging to Cinara sp. (Szelegiewicz, 1962; Blackman \& Eastop, 1994). Only 5 of them have both winged and wingless males. These include: Cinara cembrae, Cinara kochiana, Cinara pini, Cinara edulis and Cinara pruinosa. A possibility of developing both winged and wingless males is also noted for Chaitophorus salijaponicus niger, depending on geographical location (Blackman \& Eastop, 1994) and Schizaphis (Paraschizaphis) acori (Minks \& Harrewijn, 1987). This study indicates that $C$. mordvilkoi can produce both winged and wingless males. Winged males were recorded along with wingless morphs in the third year of this study. The third year differed in that the fecundity of each generation was lower than in previous years, particularly that of B generation. The polyphenism of female morphs depends on habitat conditions (Hardie \& Lees, 1985; Dixon, 1998; Braendle et al., 2006). The development of winged females is induced by different factors such as overcrowding, contact with other individuals, quality of the host plant (poor nutrition) or its age and interactions with parasitoids or pathogens (Heie, 1980; Dixon, 1998; Braendle et al., 2006). Unlike females, winged males are genetically determined (Smith \& MacKay, 1989; Braendle et al., 2006). The production of winged or wingless males is controlled by a single gene on the $\mathrm{X}$ chromosome called aphicarus (api) (Smith \& MacKay, 1989; Caillaud et al., 2002; Braendle et al., 2005). The costs and advantages of producing wingless or winged males, however, are unknown (Braendle et al., 2006).

Monoecious species, which develop only on one host plant, can be considered to have a particular gene pool. Genetically similar individuals created by parthenogenesis are adapted to particular environmental conditions. Winged males fly to other individual plants of the same host plant and thus can copulate with females from other populations. The appearance of winged males, which ensure migration, is thus probably related to increasing species diversity and consequently ensure species flexibility in changing environmental conditions. Dispersal is one way of preventing inbreeding both in insects and vertebrates (Pusey \& Wolf, 1996; Szulkin et al., 2013). Thus the production of winged males by $C$. mordvilkoi possibly serves to prevent inbreeding and increases the diversity of monoecious populations, in which in most years only wingless males are produced. The fact that winged males occur from time to time might ensure out-breeding and increase population flexibility. However, it is only a hypothesis and requires further study.

Morphological traits of the winged males confirm that they like winged females are adaptated for flying. Winged males of C. mordvilkoi have longer antennae and an increased number of rhinaria on their antennal segments. Winged females have better developed rhinaria, which act as olfactory organs during flight (Dixon, 1998). Winged females also have more secondary rhinaria than apterous famales. Also the males of host-alternating species are characterized by a higher number of rhinaria than those of non-host-alternating species (Heie, 1995). Morphological traits of winged males of $C$. mordvilkoi, particularly the number of rhinaria on segments IV and V of the antennae, can be used to distinguish between $C$. mordvilkoi and $C$. cupressi, which so far are the only species of Cinara (Cupressobium) with winged males (Heie, 1995).

In all the morphs described antennal segment VI is longer than that of segment V. This confirms earlier data published for apterous viviparous females (Pašek, 1954; Durak, 2011). Some authors, e.g. Mamontova (1972) and Danielson \& Carter (1992) indicate that the lengths of antennal segments V and VI are equal in these species, however, this study indicates that segment VI is longer than segment $\mathrm{V}$.

C. mordvilkoi is difficult to find in its natural habitat. This is because of the nature of its life cycle, which involves moving during the growing season from the leaved parts of plants to the roots or branches close to the ground and a low fecundity of each of the generations. The polymorphism and dispersal of males maintains the genetic diversity of small populations of monoecious species, which in the course of evolution have evolved wingless males.

\section{REFERENCES}

BinAzzi A. 1996: Contributions to the knowledge of the conifer aphid fauna. XXV. Cinara (Cupressobium) mordvilkoi Pasek new to the fauna of Italy, with description of the alate viviparous female (Aphididae Lachninae). — Redia 79: 137-142.

Blackman R.L. \& Eastop V.F. 1994: Aphids on the World's Trees. An identification and Information Guide. CAB International and The Natural History Museum, London [An updated digital version is available at www.aphidsonworldsplants.info]

Borowiak-SoBKowiak B. 2005: Bionomy and ecology of Aphis idaei v. d. Goot on raspberry. — Aphids Hemipt. Insects 11: 5-16.

Borowiak-SoBkowiak B. 2006: Bionomy and ecology of Amphorophora idaei (Börn.) on raspberry. - J. Plant Prot. Res. 46: 169-180.

Borowiak-SoBKowiak B. \& DuraK R. 2012: Biology and ecology of Appendiseta robiniae (Hemiptera, Aphidoidea) - an alien species in Europe. - Cent. Eur. J. Biol. 7: 487-494.

Braendle C., Friebe I., Caillaud M.C. \& Stern D.L. 2005: Genetic variation for an aphid wing polyphenism is genetically linked to a naturally occurring wing polymorphism. - Proc. Biol. Sci. 272: 657-664. 
Braendle C., Davis G.K., Brisson J.A. \& Stern D.L. 2006: Wing dimorphism in aphids. - Heredity 97: 192-199.

Caillaud M.C., Boutin M., Braendle C. \& Simon J.C. 2002: A sex-linked locus controls wing polymorphism in males of the pea aphid, Acyrthosiphon pisum (Harris). - Heredity 89: $346-352$.

DANIElsSON R. \& CARTER C. 1992: Cinara smolandiae sp. n. from Juniperus communis in Sweden and key to the species in the subgenus Cupressobium Borner (Homoptera: Aphidoidea: Lachnidae). - Entomol. Scand. 23: 475-479.

Dedryver C.A., Le Gallic J.F., Gauthier J.P. \& Simon J.C. 1998 Life cycle of the cereal aphid Sitobion avenae F.: Polymorphism and comparison of life history traits associated with sexuality. - Ecol. Entomol. 23: 123-132.

Dixon A.F.G. 1977: Aphid ecology: life cycles, polymorphism and population regulation. - Annu. Rev. Ecol. Syst. 8: 329353.

Dixon A.F.G. 1998: Aphid Ecology. 2nd ed. Chapman \& Hall, London, $300 \mathrm{pp}$.

DURAK R. 2011: Molecular and morphological identification of Cinara juniperi (De Geer) and C. mordvilkoi (Pašek) (Hemiptera, Aphididae). — Bull. Insectol. 64: 195-199.

DURAK R. 2014: The overwintering strategy of the anholocyclic aphid Cinara tujafilina. - Physiol. Entomol. [in press].

Durak R. \& Borowiak-SobKowiak B. 2013: Influence of temperature on the biological parameters of the anholocyclic species Cinara tujafilina (Hemiptera: Aphidoidea). - Cent. Eur. J. Biol. 8: 570-577.

Durak R., Borowiak-SobKowiak B. \& Socha M. 2007: Bionomy and ecology of Cinara cupressi (Buckton, 1881) (Hemiptera, Aphidoidea). - Pol. J. Entomol. 76: 107-113.

HARDIE J. \& LEES A.D. 1985: Endocrine control of polymorphism and polyphenism. In Kerkut G.A. \& Gilbert L.I. (eds): Comp. Insect Physiol. Biochem. Pharmacol. 8: 441-449.

HeIE O.E. 1980: The Aphidoidea (Hemiptera) of Fennoscandia and Denmark. I. Fauna Entomologica Scandinavica 9. Scandinavian Science Press, Klampenborg, 236 pp.

HeIE O.E. 1995: The Aphidoidea (Hemiptera) of Fennoscandia and Denmark. VI. Fauna Entomologica Scandinavica 31. Brill, Leiden, $217 \mathrm{pp}$.

Helden A.J. \& Dixon F.G. 1997: Inbreeding and egg hatching success in Sitobion avenae. - Ecol. Entomol. 22: 124-126.
HerczeK A., JasińsKa J. \& KarwańSKa J. 1977: Plant lice (Homoptera: Aphidoidea) from Brenna region (Beskid Śląski Mountains). - Acta Biol. 3: 67-86.

HuAnG M.H. \& CAillaud M.C. 2012: Inbreeding avoidance by recognition of close kin in the pea aphid, Acyrthosiphon pisum. J. Insect Sci. 12: 1-13.

KAWADA K. 1987: Polymorphism and morph determination. In Minks A.K. \& Harrewijn P. (eds): Aphids, Their Biology, Natural Enemies and Control. Vol. 2A. Elsevier, Amsterdam, pp. 255-268.

Klimaszewski S.M., Szelegiewicz H. \& Wojciechowski W. 1977: Biochemische Untersuchungen an der Kienläusen Cinara mordvilkoi (Pašek, 1954) und C. juniperi (De Geer, 1773) (Homoptera, Lachnidae). - Prac. Nauk. Uniw. Ślaskiego 175: 123-129.

Mamontova V.O. 1972: Popelizi-Ljachnidi. - Fauna Ukraini 20(7): 1-228.

Minks A.K. \& Harrewijn P. (eds) 1987: Aphids, Their Biology, Natural Enemies and Control. Vol. 2A. Elsevier, Amsterdam, $450 \mathrm{pp}$.

MiYAZAKI M. 1987: Forms and morphs of aphids. In Minks A.K. \& Harrewijn P. (eds): Aphids, Their Biology, Natural Enemies and Control. Vol. 2A. Elsevier, Amsterdam, pp. 27-50.

Mustafa T.M. 1987: Reproductive biology and population studies of the cypress aphid, Cinara cupressi (Buckton) and pine aphid, C. maritime (Dafour). - Dirasat 14: 99-105.

PAšEK V. 1954: Aphids Attacking Coniferous Trees in Czechoslovakian Forests. Slovak Academy of Science, Bratislava, 319 pp.

Pusey A. \& Wolf M. 1996: Inbreeding avoidance in animals. Trends Ecol. Evol. 11: 201-206.

Sмith M.A.H. \& MacKay P.A. 1989: Genetic variation in male alary polymorphism of pea aphid, Acyrthosiphon pisum. Entomol. Exp. Appl. 51: 125-132.

Szelegiewicz H. 1962: Materiały do poznania fauny mszyc (Homoptera, Aphididae) Polski. I. Podrodzina Lachninae. Fragm. Faun. 6: 63-96.

Szulkin M., Stopher K.V., Pemberton J.M. \& Reid J.M. 2013: Inbreeding avoidance, tolerance or preference in animals? Trends Ecol. Evol. 28: 205-211.

Received August 19, 2013; revised and accepted March 12, 2014 Prepublished online May 27, 2014 